\title{
Grevillea juncifolia Hook. and Grevillea robusta A. Cunn. Ex. R. Br. Methanolic Leaf and Flower Extracts Inhibit the Growth of Gram Positive and Gram Negative Bacteria
}

\author{
Ian Edwin Cock ${ }^{1,2, *}$ \\ 'School of Environment and Science, Griffith University, 170 Kessels Rd, Nathan, Brisbane, Queensland, AUSTRALIA. \\ 2Environmental Futures Research Institute, Griffith University, 170 Kessels Rd, Nathan, Brisbane, Queensland, AUSTRALIA.
}

\begin{abstract}
Introduction: The development of multi-antibiotic resistant strains of bacteria has necessitated the search for new effective antibacterial therapies. Several Grevillea spp. were used traditionally to treat pathogenic illness and are rich in phytocompounds with antibacterial activity. Despite this, the antibacterial activity of Australian Grevillea spp. extracts have not been extensively examined. Methods: The ability of G. juncifolia and G. robusta leaf and flower extracts to inhibit the growth of gram-negative and gram-positive bacterial species and some fungi was investigated by disc diffusion assays. The growth inhibitory activity was further quantified by MIC determination. Toxicity was determined using the Artemia franciscana nauplii bioassay. Results: The G. juncifolia and G. robusta extracts were good inhibitors of the growth of both gram-positive and gram-negative bacteria yet were completely ineffective against all fungal species tested. The leaf extracts generally had better antibacterial activity than the flower extracts. The G. juncifolia leaf extract was a particularly good inhibitor of A. faecalis, P. fluorescens, Y. entercolitica and B. subtilis growth, with MIC values of $62,533,736$ and $682 \mu \mathrm{g} / \mathrm{mL}$ respectively. The G. robusta leaf extract was a potent inhibitor of $B$. cereus and $B$. subtilis growth (145 and
\end{abstract}

$83 \mu \mathrm{g} / \mathrm{mL}$ respectively). That extract was also a good inhibitor of $A$. faecalis, P. fluorescens, S. salford, S. aureus and S. epidermidis growth, albeit with substantially higher MIC values. In contrast, none of the extracts inhibited fungal growth. All extracts were determined to be non-toxic in the Artemia franciscana nauplii bioassay, indicating their safety for the treatment of bacterial infections. Conclusion: The lack of toxicity of the G. juncifolia and G. robusta extracts and their growth inhibitory bioactivity against grampositive and gram-negative bacteria indicate their potential in the development of new antibiotic chemotherapies.

Key words: Australian plants, Proteaceae, Spider flower, Traditional medicine, Herbal medicine, Antibacterial, Antibiotic resistant bacteria, Toxicity.

\section{Correspondence: \\ Dr. Ian Edwin Cock}

School of Environment and Science, Griffith University, 170 Kessels Rd, Nathan, Brisbane, Queensland 4111, AUSTRALIA.

Phone no: +61737357637

E-mail: I.Cock@griffith.edu.au

DOI: $10.5530 /$ pc.2019.3.23

\section{INTRODUCTION}

The discovery of penicillin by Alexander Fleming in 1928 changed the way bacterial infections were treated and has resulted in substantially decreased mortalities towards many pathogenic infections. That discovery resulted in a major paradigm shift in the way that medical science sought to develop new antibiotic chemotherapies. Since that time, research has focussed on screening for microbially derived antibiotic agents to provide the majority of our first-generation drugs. Despite many significant advances in the treatment of pathogenic disease, bacteria have developed resistance to all of the antibiotics commonly used clinically. ${ }^{1}$ Several medicinally important bacterial pathogens have become either extremely (XDR) or totally drug resistant (TDR) to common clinically used antibiotics $^{1}$ and there are now limited therapeutic options for the diseases caused by these pathogens. This problem is expected to worsen in the future as bacteria exchange resistance genes and more strains become multi-drug resistant (MDR). The development of alternative antibacterial treatment modalities has become crucial and is considered by the World Health Organisation (WHO) to be one of the most serious challenges facing medical science. ${ }^{2}$ For a number of reasons reviewed elsewhere, ${ }^{1}$ it is unlikely that the previous methods of antibiotic discovery/development will be as successful in the future and new treatment modalities are urgently required.

Traditional medicines and herbal remedies have great potential for antimicrobial drug development and there has recently been a substantial increase in interest in this field..$^{3-5}$ The genus Grevillea (family Proteaceae) consists of approximately 360 species native to rainforest and open regions of Australia, New Guinea, New Caledonia and Sulawesi, with the greatest diversity occurring in Australia. Grevilleas are commonly referred to as spider flower trees due to the appearance of their flowers and are also often referred to as silky oaks. Grevillea flowers were used as a food source by Australian Aborigines. The flowers were sucked for their sweet nectar or used to make sweet drinks. ${ }^{6}$ They also had roles as traditional bush medicines for Australian Aborigines. ${ }^{6,7}$ The leaves were used to treat wounds and sores, skin diseases as well as diarrhoea and dysentery. ${ }^{6,7}$ Many of these diseases are caused by bacterial pathogens. Grevillea spp. decoctions were also used as potent bacteriocides and are reputed to have broad-spectrum inhibitory activity. ${ }^{6,7}$ Unfortunately most of our understanding of the antimicrobial potential of Australian Grevillea species is anecdotal, with few species being thoroughly studied. Indeed, we were only able to find two studies that have examined Grevillea spp. extracts for antibacterial activity. ${ }^{8,9}$ Unfortunately, both of these studies screened for antibacterial activity using a single, relatively high extract concentration and did not determine MIC values, making it impossible to benchmark the efficacy of these extracts against other plant species and conventional antibiotics. Whilst much work is needed to determine the chemical composition of the Grevillea spp., G. robusta leaf methanolic extracts have been reported to contain the novel compounds graviquinone (Figure 1e), methyl-5-ethoxy-2-hydrocinnamate (Figure 1f) and cis-3-hydroxy-5-pentadecylcyclohedxanone (Figure 1g). ${ }^{10}$ The same study also detected multiple other compounds including methyl 2, 5-dihydroxycinnamate (Figure 1h) gravicycle (Figure 1i) and quercetin (Figure $1 \mathrm{j}$ ).

Despite their traditional use and the earlier studies confirming antibacterial activity against limited bacterial panels, many Grevillea spp. are yet to be thoroughly evaluated for antibacterial activity. Grevillea juncifolia Hook. (Figure 1a) (commonly known as honeysuckle grevillea, honey grevillea and honeysuckle spider flower) is a shrub that is native to 


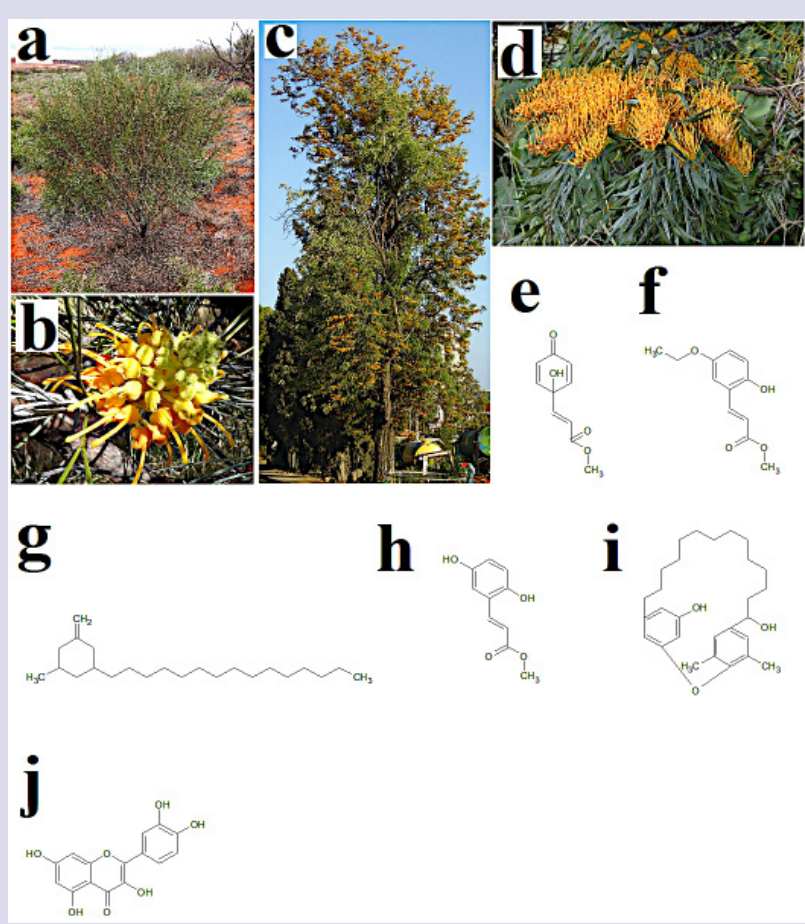

Figure 1: (a) G. juncifolia whole plant, (b) G. juncifolia flowers, (c) G. robusta whole plant, (b) G. robusta flowers, as well as the G. robusta phytochemical compounds (e) graviquinone, (f) methyl5-ethoxy-2-hydrocinnamate, (g) cis-3-hydroxy-5-pentadecylcyclohedxanone, (h) methyl 2,5-dihydroxycinnamate (i) gravicycle and (j) quercetin.

inland regions of Australia. It produces yellow or orange flowers (Figure 1b), with flowering generally peaking between July and November each year. Grevillea robusta A. Cunn. Ex R. Br (Figure 1c) (commonly known as southern silky oak, silky oak, Australian silky oak) is a tall evergreen tree that grows to $40 \mathrm{~m}$ tall. It produces yellowish-orange one-sided "toothbrush-like" flowers (Figure 1d) from September to November. The current study was undertaken to screen G. juncifolia and G. robusta leaf and flower extracts for the ability to inhibit the growth of panels of gram-positive and gram-negative bacterial pathogens and three fungal species.

\section{MATERIALS AND METHODS}

\section{Plant collection and extraction}

Grevillea juncifolia Hook. and Grevillea robusta A. Cunn. ex R. Br. leaves and flowers were obtained from verified trees on the southside of Brisbane, Australia. The leaf samples were dried in a Sunbeam food dehydrator, ground to a coarse powder and stored at $-30^{\circ} \mathrm{C}$ until use. A volume of 50mL of AR grade methanol (Ajax Fine Chemicals, Australia) was added to $1 \mathrm{~g}$ of each plant material and extracted individually for $24 \mathrm{~h}$ at $4^{\circ} \mathrm{C}$ with gentle shaking. The extract was filtered through filter paper (Whatman No. 54) under vacuum, followed by lyophilisation. The resultant pellets were weighed to determine the extraction yield and subsequently dissolved in $10 \mathrm{~mL}$ sterile deionised water (containing $1 \%$ DMSO). The extracts were passed through $0.22 \mu \mathrm{m}$ filter (Sarstedt) and stored at $4^{\circ} \mathrm{C}$ until use.

\section{Qualitative phytochemical studies}

Phytochemical analysis of the Grevillea spp. leaf and flower extracts for the presence of saponins, phenolic compounds, flavonoids, phytosteroids, triterpenoids, cardiac glycosides, anthraquinones, tannins and alkaloids was conducted by standard assays. ${ }^{11-13}$

\section{Antibacterial screening Test microorganisms}

All media was purchased from Oxoid Ltd., Australia. The reference strains of E. coli (ATCC157293) and Klebsiella pneumoniae (ATCC31488) were purchased from American Tissue Culture Collection (ATCC), USA. Clinical isolate microbial strains of Aeromonas hydrophilia, Alcaligenes feacalis, Aspergillus niger, Bacillus cereus, Bacillus subtilis, candidia albicans, Citrobacter freundi, Pseudomonas aeruginosa, Pseudomonas fluorescens, Sacchromyces cerevisiae, Salmonella salford, Serratia marcescens, Staphylococcus aureus, Staphylococcus epidermidis and Yersinia entercolitica strains were obtained from Ms. Michelle Mendell and Ms. Jane Gifkins, Griffith University. All stock cultures were subcultured and maintained in nutrient broth at $4^{\circ} \mathrm{C}$. The fungal strains were cultured in Sabourand broth (Oxoid, Australia).

\section{Evaluation of antimicrobial activity}

Antimicrobial activity of the Grevillea spp. leaf and flower extracts was determined using a modified disc diffusion assay. ${ }^{14-16}$ Briefly, $100 \mu \mathrm{L}$ of the each bacterial suspension in log phase was spread onto individual nutrient agar plates (or Sabourand agar for the fungal strains) and the extracts were tested for antibacterial activity using $5 \mathrm{~mm}$ sterilised filter paper discs. The discs were each infused with $10 \mu \mathrm{L}$ of the individual plant extract, allowed to dry and placed onto the inoculated plates. The plates were allowed to stand at $4^{\circ} \mathrm{C}$ for $2 \mathrm{~h}$ before incubation at $37^{\circ} \mathrm{C}$ for $24 \mathrm{~h}$. The diameters of the zones of inhibition (ZOIs) were measured to the closest whole millimetre. Each assay was performed three times in triplicate $(n=9)$. Mean values $( \pm$ SEM) are reported in this study. Standard discs of ampicillin $(10 \mu \mathrm{g})$, chloramphenicol $(10 \mu \mathrm{g})$ and nystatin $(100 \mu \mathrm{g})$ were obtained from Oxoid, Australia and were used as positive controls to compare antibacterial and antifungal activity. Filter discs infused with $10 \mu \mathrm{L}$ of distilled water were used as a negative control.

\section{Minimum inhibitory concentration (MIC) determination}

The minimum inhibitory concentration (MIC) of each extract against susceptible bacteria was determined as previously described. ${ }^{17-19}$ Briefly, the Grevillea spp. leaf and flower extracts were diluted in deionised water (1\% DMSO) and tested across a range of concentrations. Discs were individually infused with $10 \mu \mathrm{L}$ of each extract, allowed to dry and placed onto the inoculated plates. The assay was completed as outlined above and graphs of the ZOI versus ln concentration were plotted for each extract. Linear regression was used to determine the MIC values of each extract.

\section{Artemia franciscana nauplii toxicity screening}

Toxicity was tested using an adapted Artemia franciscana nauplii lethality assay. ${ }^{20-22}$ Briefly, A. franciscana nauplii were incubated in the presence of the extracts, reference toxin $(1 \mathrm{mg} / \mathrm{mL}$ potassium dichromate) or artificial seawater (negative control) at $25 \pm 1^{\circ} \mathrm{C}$ under artificial light. All treatments were performed three times in triplicate $(n=9)$. The number of dead were counted in each well at $24 \mathrm{~h}$ and $48 \mathrm{~h}$. At the completion of the $48 \mathrm{~h}$ exposure period, the remaining live nauplii were sacrificed and the total number of nauplii in each well were counted and used to calculate the $\%$ mortality per well. $\mathrm{LC}_{50}$ values were calculated for each treatment using probit analysis. 
Table 1: The mass of dried extracted material, the concentration after resuspension in deionised water and qualitative phytochemical screenings of the Grevillea spp. extracts.

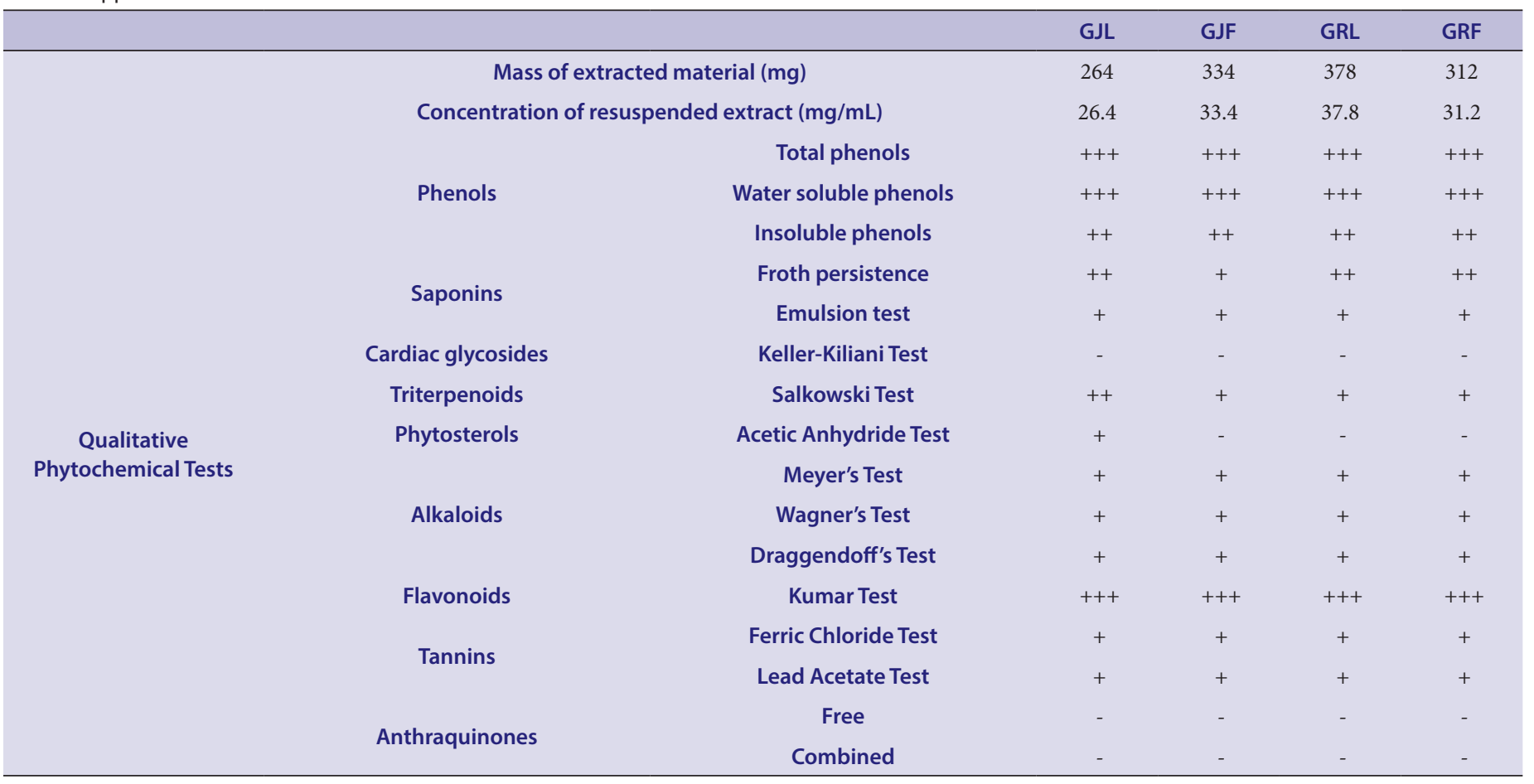

+++ indicates a large response; ++ indicates a moderate response; + indicates a minor response; - indicates no response in the assay; GJL = Grevillea juncifolia leaf extract; GJF = Grevillea juncifolia flower extract; GRL = Grevillea robusta leaf extract; GRF = Grevillea robusta flower extract.

\section{Statistical analysis}

Data are expressed as the mean \pm SEM of three independent experiments with internal triplicates $(n=9)$. One-way ANOVA was used to calculate statistical significance between control and treated groups, with a $P$ value $<0.01$ considered to be statistically significant.

\section{RESULTS}

\section{Liquid extraction yields and qualitative phytochemical screening}

Extraction of $1 \mathrm{~g}$ of dried and powdered Grevillea spp. leaves and flowers with methanol yielded $264-378 \mathrm{mg}$ of extracted material (Table 1). The extracts were resuspended in $10 \mathrm{~mL}$ of deionised water (containing $1 \%$ DMSO), resulting in the extract concentrations shown in Table 1. Qualitative phytochemical studies showed that all of the extracts had similar phytochemical profiles. All contained high levels of phenolic compounds and flavonoids, as well as moderate levels of saponins. Lower levels of triterpenoids, alkaloids and tannins were also detected. Cardiac glycosides and anthraquinones were completely absent or below the detection thresholds for these assays.

\section{Antimicrobial activity}

To determine the growth inhibitory activity of the Grevillea spp. leaf and flower extracts, aliquots $(10 \mu \mathrm{L})$ of each extract were screened in the disc diffusion assay. Varied effects were noted for the Grevillea spp. leaf and flower extracts against the gram-negative bacterial species, athough the extracts were ineffective at inhibiting the growth of many the gram-negative bacterial species tested (Figure 2). In contrast, both positive control antibiotics (ampicillin and chloramphenicol) were effective growth inhibitors, with ZOI's of up to $14.3 \mathrm{~mm}$ (ampicillin against $A$. faecalis). However, there was some notable activity against three gram-negative bacterial species. A. faecalis was particularly suscep-

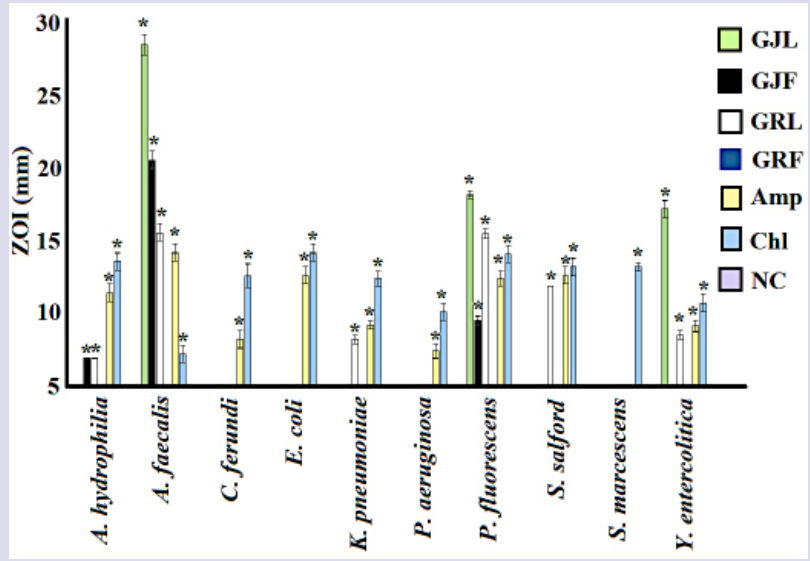

Figure 2: Growth inhibitory activity of Grevillea spp. leaf and flower extracts and reference antibiotics against gram-negative bacterial species measured as ZOIs $(\mathrm{mm}) \pm \mathrm{SEM}$. Ampicillin (Amp) and chloramphenicol (Chl) standard discs $(10 \mu \mathrm{g})$ were used as positive controls. GJL $=G$. juncifolia leaf extract; $\mathrm{GJF}=\mathrm{G}$. juncifolia flower extract; $\mathrm{GRL}=\mathrm{G}$. robusta leaf extract; $\mathrm{GRF}=\mathrm{G}$. robusta flower extract; $\mathrm{NC}=$ negative control. All assays were completed three times, each with internal triplicates $(n=9)$ and the results are expressed as mean zones of inhibition $(\mathrm{mm}) \pm \mathrm{SEM}$.

tible to the Grevillea spp. extracts, with ZOIs of 28.7, 20.7 and $15.7 \mathrm{~mm}$ recorded for the G. juncifolia leaf and flower extracts and the G. robusta leaf extract respectively. Similarly, 18.3, 9.6 and 15.6mm ZOIs were noted for the G. juncifolia leaf and flower extracts and the G. robusta leaf extract respectively against $P$. fluorescens, whilst 17.3 and $8.6 \mathrm{~mm}$ were measured 


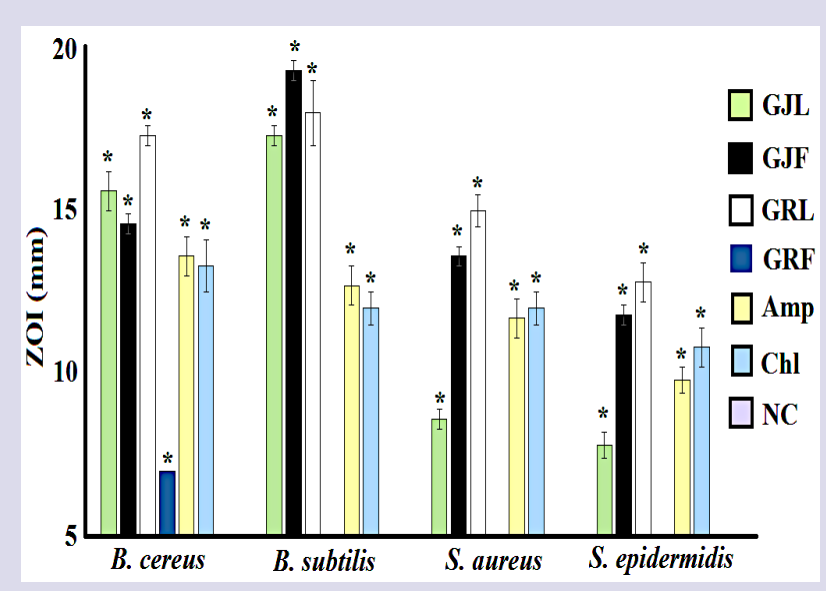

Figure 3: Growth inhibitory activity of Grevillea spp. leaf and flower extracts and reference antibiotics against gram-positive bacterial species measured as ZOls $(\mathrm{mm}) \pm \mathrm{SEM}$. Ampicillin (Amp) and chloramphenicol (Chl) standard discs $(10 \mu \mathrm{g})$ were used as positive controls. GJ $=G$. juncifolia leaf extract; $\mathrm{GJF}=\mathrm{G}$. juncifolia flower extract; $\mathrm{GRL}=\mathrm{G}$. robusta leaf extract; $\mathrm{GRF}=\mathrm{G}$. robusta flower extract; $\mathrm{NC}=$ negative control. All assays were completed three times, each with internal triplicates $(n=9)$ and the results are expressed as mean zones of inhibition $(\mathrm{mm}) \pm$ SEM. for the G. juncifolia and G. robusta leaf extracts when tested against Y. entercolitica.

A different trend was noted against the gram-positive bacterial species. With the exception of the G. robusta flower extract, all extracts were strong inhibitors of the growth of all gram-positive bacteria (Figure 3). Indeed, ZOIs in the range $15-20 \mathrm{~mm}$ were measured for these extracts against both Bacillus spp. These ZOIs compared particularly favourably to the ampicillin and chloramphenicol controls, which produced ZOIs in the range $12-14 \mathrm{~mm}$. This is noteworthy as both of these controls were tested at relatively high doses $(10 \mu \mathrm{g} / \mathrm{disc})$. Furthermore, the control antibiotics are pure compounds, whereas the extracts are crude mixtures and the active compound(s) would be expected to be a minor $\%$ of the overall extracts mass. Therefore, these extracts may be particularly promising as targets for antibiotic drug discovery.

Grevillea spp. leaf and flower extracts were also effective inhibitors of S. aureus and S. epidermidis growth (Figure 3). However, the size of these ZOIs is indicative of only moderate inhibitory activity. Interestingly, all extracts were completely devoid of antifungal activity, with ZOIs not significantly different to those determined for the negative control (results not shown). In contrast, the nystatin control was a good inhibitor of the growth of all fungal species, indicating that the assay was functioning correctly.

The antimicrobial efficacy was further quantified by determining the MIC value against each susceptible bacterial species (Table 2). The leaf extracts of each species were generally better inhibitors of bacterial growth than the corresponding flower extracts for both Grevillea species. The G. juncifolia leaf extract was a particularly potent inhibitor of A. faecalis, P. fluorescens and Y. entercolitica (MICs of 62, 533 and $736 \mu \mathrm{g} / \mathrm{mL}$ respectively). However, there were some notable exceptions to these trends. The G. juncifolia flower extract was a more potent growth inhibitor of all gram-positive bacterial species than the corresponding leaf extract. In comparison, the G. juncifolia leaf extract was a substantially more potent inhibitor of gram-negative bacterial growth than was the flower extract, whilst the G. robusta leaf extract was much more

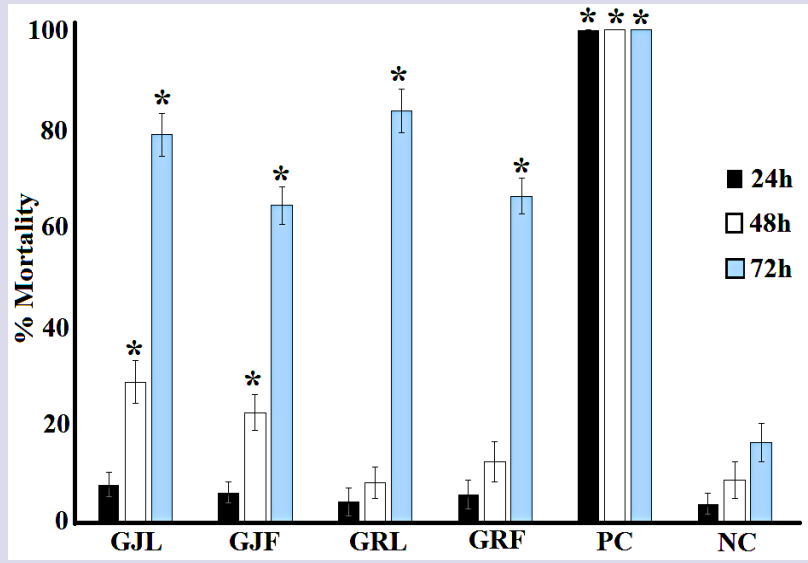

Figure 4: The lethality of the Grevillea spp. leaf and flower extracts $(2000 \mu \mathrm{g} / \mathrm{mL})$, potassium dichromate control $(1000 \mu \mathrm{g} / \mathrm{mL})$ and seawater (negative control) following 24,48 and $72 \mathrm{~h}$ exposure. $\mathrm{GJ}=$ Grevillea juncifolia leaf extract; GJF = Grevillea juncifolia flower extract; GRL = Grevillea robusta leaf extract; GRF = Grevillea robusta flower extract. All bioassays were performed three times in triplicate $(n=9)$ and are expressed as mean \pm SEM. * indicates results that are significantly different to the untreated (seawater) control at the equivalent exposure time $(P<0.01)$.

Table 2: Minimum inhibitory concentrations $(\mu \mathrm{g} / \mathrm{mL})$ of the Grevillea spp. leaf and flower extracts against each susceptible bacterial strain and $L C_{50}$ values $(\mu \mathrm{g} / \mathrm{mL})$ against Artemia nauplii.

\begin{tabular}{cccccc}
\hline & \multirow{2}{*}{$\begin{array}{c}\text { Exposure } \\
\text { Organism }\end{array}$} & \multicolumn{5}{c}{ MIC or LC $_{50}(\mathrm{ug} / \mathrm{mL})$} \\
\cline { 5 - 6 } time $(\mathrm{h})$ & $\mathrm{GJL}$ & $\mathrm{GJF}$ & $\mathrm{GRL}$ & $\mathrm{GRF}$ \\
\hline A. hydrophilia & 24 & - & 2285 & 1788 & - \\
A. faecalis & 24 & 62 & 276 & 886 & - \\
K. pneumoniae & 24 & - & - & 1146 & - \\
P. fluorescens & 24 & 533 & 1260 & 829 & - \\
S. salford & 24 & - & - & 869 & - \\
Y. entercolitica & 24 & 736 & - & 1185 & - \\
B. cereus & 24 & 1055 & 463 & 145 & 2360 \\
B. subtilis & 24 & 682 & 226 & 83 & - \\
S. aureus & 24 & 1065 & 686 & 380 & - \\
S. epiedermidis & 24 & 1387 & 1046 & 623 & - \\
& 24 & $\mathrm{CND}$ & $\mathrm{CND}$ & $\mathrm{CND}$ & $\mathrm{CND}$ \\
Artemia nauplii & 48 & $\mathrm{CND}$ & $\mathrm{CND}$ & $\mathrm{CND}$ & $\mathrm{CND}$ \\
& 72 & 785 & 923 & 662 & 880 \\
\hline
\end{tabular}

Numbers indicate the mean MIC or $\mathrm{LC}_{50}$ values of three independent experiments in triplicate $(\mathrm{n}=9) . \mathrm{GJL}=$ G. juncifolia leaf extract; $\mathrm{GJF}=G$. juncifolia flower extract; $\mathrm{GRL}=G$. robusta leaf extract; $\mathrm{GRF}=G$. robusta flower extract; - indicates that the extract was inactive at all concentrations tested; CND indicates that an $\mathrm{LC}_{50}$ could not be determined as the mortality did not exceed $50 \%$ at any concentration tested.

potent against the gram-positive bacteria than the G. robusta flower extract.

\section{Quantification of toxicity}

The toxicity of the Grevillea spp. extracts was initially tested at 2mg/ $\mathrm{mL}$ in the A. franciscana nauplii bioassay (Figure 4). The mortality in 
the presence of all extracts was not significantly different to that of the untreated control at $24 \mathrm{~h}$ and thus all extracts were deemed to be non-toxic. Extracts with $24 \mathrm{~h} \mathrm{LC}_{50}$ values $>1000 \mu \mathrm{g} / \mathrm{mL}$ have previously been defined as non-toxic. ${ }^{20,21}$ In contrast, the potassium dichromate positive control induced substantial mortality within 4 h (results not shown), with $100 \%$ mortality induction seen by $24 \mathrm{~h}$. The mortality induction remained relatively low for the Grevillea spp. extracts at $48 \mathrm{~h}$. Indeed, the $\%$ mortality induction was substantially $<50 \%$ for all extracts following $48 \mathrm{~h}$ exposure and therefore it was not possible to determine $\mathrm{LC}_{50}$ values for any of the Grevillea spp. extracts at 24 or $48 \mathrm{~h}$ (Table 2). In contrast, the mortality was substantially increased for all extracts at $72 \mathrm{~h}$. However, as toxicity in this assay is defined following $24 \mathrm{~h}$ exposure, all extracts were deemed to be nontoxic.

\section{DISCUSSION}

Despite the initial potency of many antibiotic chemotherapies, recent increases in bacterial resistance to many antibiotics has made the development of new antibiotic therapies a high priority. ${ }^{1}$ A parallel decrease in the introduction of new antibiotic therapies in recent years has further compounded this problem. As a result, interest in re-evaluating medicinal plants for new antibiotic chemotherapies has escalated substantially. ${ }^{23}$ Grevillea spp. are good candidates for the development of new antibacterial drugs as they were used by Australian Aborigines to treat bacterial infections. ${ }^{6,7}$ Furthermore, several studies have reported that Grevillea spp. leaf and flower extracts are potent inhibitors of multiple bacterial species. ${ }^{8,9}$ This study has extended these earlier studies by testing Grevillea spp. leaf and flower extracts against an extended panel of bacterial pathogens and three fungal species.

The greater susceptibility of gram-positive bacteria to the Grevillea spp. leaf and flower extracts extracts noted in this study is in agreement with previously reported results for South American. ${ }^{24,25}$ African ${ }^{26,27}$ and Australian ${ }^{28}$ plant extracts. Results within our laboratory have also confirmed the greater susceptibility of gram-positive bacteria towards other Australian plant extracts. ${ }^{29-31}$ The gram-negative bacterial cell wall outer membrane is thought to act as a barrier to many substances including antibiotics. ${ }^{32}$ In contrast, other studies have demonstrated that gram-negative bacteria are often more susceptible to plant extracts from different Australian plant species. ${ }^{33-35}$

Whilst an investigation of the phytochemistry of the Grevillea spp Grevillea spp. extracts was beyond the scope of our study, high levels of polyphenolics and flavonoids, as well as moderate levels of triterpenoids and saponins were noted in the extracts in the qualitative phytochemical screening study. Lower levels of tannins were also detected. Flavonoids have well established bacterial growth inhibitory activities. ${ }^{36}$ For example, the flavonoids kaempferol and myricetin have potent growth inhibitory activity against a panel of bacteria. ${ }^{37}$ Similarly, quercetin, rutin and their corresponding glycosides inhibit the growth of Pseudomonas maltophilia and Enterobacter cloacae. ${ }^{38}$ The antimicrobial activity of terpenoids has also been extensively documented. Monoterpenoids including $\alpha$-pinene, $\beta$-pinene, sabinene, mycrene, terpinene, limonene, piperitone and $\beta$-phellandrene inhibit the growth of a panel of bacteria including several antibiotic resistant strains of Enterobacteriaceae. ${ }^{36}$ Similarly, the antibacterial activities for several sesquiterpenoids including $\alpha$-cubebene, copaene and caryophyllene have been reported. ${ }^{36}$ Furthermore, many tannin compounds have bacterial growth inhibitory activity. Gallotannins inhibit the growth of a broad spectrum of bacterial species ${ }^{39}$ through a variety of mechanisms including binding cell surface molecules including lipotoichoic acid and proline-rich cell surface proteins, ${ }^{40,41}$ and by inhibiting glucosyltransferase enzymes. ${ }^{42}$ Elligitannins are also highly potent inhibitors of bacterial growth, with MIC values as low as $62.5 \mu \mathrm{g} / \mathrm{mL}^{39,41}$ Ellagitannins have also been reported to function via several antibiotic mechanisms including interaction with cytoplasmic oxidoreductases and by disrupting bacterial cell walls. ${ }^{39,41}$ Thus, it is likely that multiple compounds within the Grevillea spp. leaf and flower extracts are contributing to the antibacterial activity reported here.

Our findings also indicate that the extracts examined were non-toxic $\left(\mathrm{LC}_{50}>1000 \mu \mathrm{g} / \mathrm{mL}\right)$ in the Artemia nauplii bioassay. Whilst toxicity was assessed in this study with the test organism A. franciscana, toxicity towards $A$. franciscana has previously been shown to correlate well with toxicity towards human cells for many toxins. ${ }^{20,21}$ However, further studies are required to determine whether this is also true for the Grevillea spp. leaf and flower extracts examined in these studies. The results of this study indicate that the Grevillea spp. leaf and flower extracts may be good candidates for antimicrobial drug discovery and further examination is warranted. Whilst the extracts examined in this report have potential as bacterial growth inhibitors, caution is needed before these compounds can be applied to medicinal purposes. Purification and identification of the bioactive components is needed to examine the mechanisms of action of these agents.

\section{CONCLUSION}

The growth inhibitory activity of the Grevillea spp. leaf and flower extracts against the gram-negative and gram-positive bacteria and their lack of toxicity towards Artemia nauplii indicate their potential for the development of new antibiotic drugs.

\section{ACKNOWLEDGEMENT}

The authors are grateful to Michelle Mendell and Jane Gifkins of Griffith University for providing the clinical bacterial and fungal strains used in this study. Financial support for this work was provided by the Environmental Futures Research Institute, Griffith University, Australia.

\section{CONFLICT OF INTEREST}

The author reports no conflicts of interest.

\section{ABBREVIATIONS}

DMSO: Dimethyl sulfoxide; $\mathbf{L C}_{50}$ : The concentration required to achieve 50 \% mortality; MIC: minimum inhibitory concentration; ZOI: zone of inhibition.

\section{REFERENCES}

1. Cheesman MJ, Ilanko A, Blonk B, et al. Developing new antimicrobial therapies: Are synergistic combinations of plant extracts/compounds with conventional antibiotics the solution?. Pharmacog Rev. 2017;11(22):57-72. DOI: 10.4103/ phrev.phrev_21_17

2. WHO. Antimicrobial Resistance. World Health Organization. 2016.

3. Sirdaarta J, Matthews B, Cock IE. Kakadu plum fruit extracts inhibit the growth of the bacterial triggers of rheumatoid arthritis: identification of stilbene and tannin components. J Funct Foods. 2015;17:610-20. DOI: 10.1016/j.jff.2015.06.019

4. Ilanko A, Cock IE. The interactive antimicrobial activity of conventional antibiotics and Petalostigma spp. extracts against bacterial triggers of some autoimmune inflammatory diseases. Pharmacog J. 2019;11(1).

5. Chowdhury AN, Ashrafuzzaman M, Ali H, et al. Antimicrobial activity of some medicinal plants against multi drug resistant human pathogens. Adv Biosci Bioeng. 2013;1(1):1-24.

6. Cock IE. Medicinal and aromatic plants-Australia. in Ethnopharmacology section, Biological, Physiological and Health Sciences. Encyclopedia of Life Support Systems. 2011.

7. Lassak EV, McCarthy T. Australian Medicinal Plants. A Complete Guide to Identification and Usage. New Holland Publishers. 2011.

8. Ullah MS, Sikder MA, Sharmin T, et al. Pharmacological activities of Grevillea robusta, a medicinal plant of Bangladesh. Bangladesh Pharm J. 2014;17(2):135-7.

9. Cock IE, Ruebhart DR. Assessment of the toxicity of selected Australian native plant extracts using the Artemia franciscana nauplii bioassay. Int J Toxicol. 2008;5(2):2

10. Chuang TH, Chan HH, WuTS, et al. Chemical constituents and biological studies 
of the leaves of Grevillea robusta. Molecules. 2011;16(11):9331-9.

11. Winnett V, Sirdaarta J, White $A$, et al. Inhibition of Klebsiella pneumonia growth by selected Australian plants: natural approaches for the prevention and management of ankylosing spondylitis. Inflammopharmacol. 2017;25(2):223-35. DOI: 10.1007/s10787-017-0328-1

12. Wright $M H$, Matthews $B$, Arnold MSJ, et al. The prevention of fish spoilage by high antioxidant Australian culinary plants: Shewanella putrefaciens growth inhibition. Int J Food Sci Technol. 2016;51(3):801-13. DOI: 10.1111/ijfs.13026

13. Mpala L, Chikowe G, Cock IE. No evidence of antiseptic properties and low toxicity of selected Aloe species. J Pharm Negative Results. 2010:1(1):10-6. DOI: 10.4103/0976-9234.68869

14. Maen A, Cock IE. Inhibitory activity of Australian cullinary herb extracts against the bacterial triggers of selected autoimmune diseases. Pharmacog Commn 2015;5(2):130-9. DOI: 10.5530/pc.2015.2.4

15. Wright $\mathrm{MH}$, Matthews $\mathrm{B}$, Greene $\mathrm{AC}$, et al. Growth inhibition of the zoonotic bacteria Bacillus anthracis by high antioxidant Australian plamts: new leads for the prevention and treatment of anthrax. Pharmacog Commn. 2015;5(3):175-89. DOI: $10.5530 /$ pc.2015.3.3

16. Sirdaarda J, Matthews B, White A, et al. GC-MS and LC-MS analysis of Kakadu plum fruit extracts displaying inhibitory activity against microbial triggers of multiple sclerosis. Pharmacog Commn. 2015;5(2):100-15. DOI: 10.5530/ pc.2015.2.2

17. Cock IE, Winnett $V$, Sirdaarta J, et al. The potential of selected Australian medicinal plants with anti-Proteus activity for the treatment and prevention of rheumatoid arthritis. Pharmacog Mag. 2015;11(42 Suppl 1):S190-208. DOI: 10.4103/0973-1296.157734

18. McManus K, Wood A, Wright MH, et al. Terminalia ferdinandiana Exell. extracts inhibit the growth of body odour forming bacteria. Int J Cosmet Sci. 2017;39(5):500-10. DOI: 10.1111/ics.12403

19. Murhekar S, Wright MH, Greene AC, et al. Inhibition of Shewanella spp. growth by Syzygium australe and Syzygium luehmannii extracts: natural methods for the prevention of fish spoilage. J Food Sci Technol. 2017;54(10):3314-26. DOI: 10.1007/s13197-017-2782-6

20. Ruebhart DR, Wikramasinghe WA, Cock IE. Protective efficacy of the antioxidants vitamin $\mathrm{E}$ and Trolox against Microcystis aeruginosa and microcystin-LR in Artemia franciscana nauplii. JToxicol Environ Health Part A. 2009;72(24):1567-75.

21. Cock IE, Ruebhart DR. Comparison of the brine shrimp nauplii bioassay and the ToxScreen-II test for the detection of toxicity associated with Aloe vera (Aloe barbadensis Miller) leaf extract. Pharmacog Res. 2009;1(2):98-101.

22. Kalt FR, Cock IE. Gas chromatography-mass spectroscopy analysis of bioactive Petalostigma extracts: Toxicity, antibacterial and antiviral activities. Pharmacog Mag. 2014;10(Suppl 1):S37-49. DOI: 10.4103/0973-1296.127338

23. Aiyegoro OA, Okoh Al. Use of bioactive plant products in combination with standard antibiotics: implications in antimicrobial chemotherapy. J Med Plants Res. 2009;3(13):1147-52

24. Paz EA, Cerdeiras MP, Fernandez J, et al. Screening of Uruguayan medicinal

\section{PICTORIAL ABSTRACT}

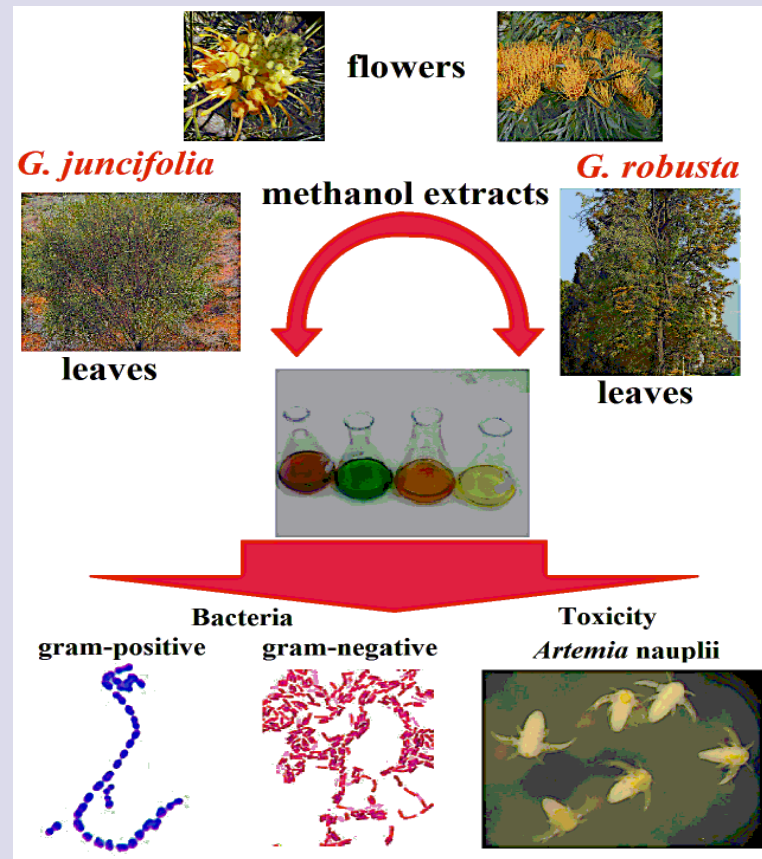

plants for antimicrobial activity. J Ethnopharmacol. 1995;45(1):67-70.

25. Mohanty S, Cock IE. Evaluation of the antibacterial activity and toxicity of Myrciaria caulifloria methanolic leaf and fruit extracts. Internet J Microbiol. 2009;7:(2).

26. Cock IE, Vuuren SFV. Anti-Proteus activity of some South African medicinal plants: Their potential for the treatment and prevention of rheumatoid arthritis. Inflammopharmacol. 2014;22(1):23-36. DOI 10.1007/s10787-013-0179-3.

27. Cock IE, Vuuren SFV. The potential of selected some South African plants with anti-Klebsiella activity for the treatment and prevention of ankylosing spondylitis. Inflammopharmacol. 2014,23(1):21-35. DOI: 10.1007/s10787-014-0222-z

28. Palombo EA, Semple SJ. Antibacterial activity of traditional Australian medicinal plants. J Ethnopharmacol. 2001;77(2-3):151-7.

29. Cock IE. Antimicrobial activity of Eucalyptus major and Eucalyptus baileyana methanolic extracts. Internet J Microbiol. 2009;6(1):31.

30. Kalt FR, Cock IE. The medicinal potential of Australian native plants from Toohey Forest, Australia. SPJNAS. 2011;28(1):41-7.

31. Chikowe G, Mpala L, Cock IE. Antibacterial activity of selected Australian Syzygium species. Pharmacog Commn. 2013;3(4):77-83. DOI: 10.5530/ pc.2013.4.11

32. Tortora GJ, Funke BR, Case CL. Microbiology: An Introduction San Francisco. Benjamin Cummings. 2001.

33. Vesoul J, Cock IE. The potential of Bunya nut as an antibacterial food agent Pharmacog Commn. 2012;2(1):74-82. DOI: 10.5530/pc.2012.1.13

34. Vesoul J, Cock IE. An examination of the medicinal potential of Pittosporum phylloraeoides: Toxicity, antibacterial and antifungal activities. Pharmacog Commn. 2011;1(2):8-17. DOI: 10.5530/pc.2012.1.13

35. Kukkonen L, Cock IE. An examination of the medicinal potential of Scaevola spinescens: Toxicity, antibacterial and antiviral activities. Pharmacog Res. 2011;3(2):85-94. DOI: 10.4103/0974-8490.81955

36. Cock IE. The phytochemistry and chemotherapeutic potential of Tasmannia lanceolata (Tasmanian pepper): A review. Pharmacog Commn. 2013;3(4):13-25. DOI: $10.5530 / p c .2013 .4 .3$

37. Cai L, Wu CD. Compounds from Syzygium aromaticum possessing growth inhibitory activity against oral pathogens. J Nat Prod. 1996:59(10):987-90.

38. Waage SK, Hedin PA. Quercetin 3-O-galactosyl-(1, 4, 6)-glucoside, a compound from narrow leaf vetch with antibacterial activity. Phytochem. 1985;24(2):243-5

39. Buzzini P, Arapitsas $P$, Goretti M, et al. Antimicrobial activity of hydrolysable tannins. Mini Rev Med Chem. 2008;8(12):1179-87.

40. Wolinsky LE, Sote EO. Isolation of natural plaque-inhibiting substances from 'Nigerian chewing sticks'. Caries Res. 1984;18(3):216-25.

41. Hogg SD, Embery G. Blood-group-reactive glycoprotein from human saliva interacts with lipoteichoic acid on the surface of Streptococcus sanguis cells. Arch Oral Biol. 1982;27(3):261-8

42. Wu-Yuan CD, Chen CY, Wu RT. Gallotannins inhibit growth, water-soluble glucan synthesis and aggregation of Streptococci mutans. J Dent Res. 1988;67(1):51-5.

\section{SUMMARY}

- Methanolic G. juncifolia and G. robusta leaf and flower extracts were screened for the ability to block the growth of a panel of bacteria.

- The growth inhibition of both gram-positive and gram-negative bacteria and three fungi was tested.

- The antibacterial activity was quantified by determining the MIC values of each extract.

- Toxicity of the G. juncifolia and G. robusta extracts was determined using the Artemia nauplii toxicity bioassay.

\section{ABOUT AUTHORS}

Dr. Ian Cock leads a research team in the Environmental Futures Research Institute and the School of Environment

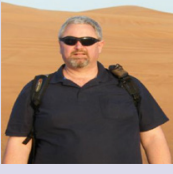
and Science at Griffith University, Australia. His research involves bioactivity and phytochemical studies into a variety of plant species of both Australian and international origin, including Aloe vera, South Asian and South American tropical fruits, as well as Australia plants including Scaevola spinescens, Pittosporum phylliraeoides, Terminalia ferdinandiana (Kakadu plum), Australian Acacias, Syzygiums, Petalostigmas and Xanthorrhoea johnsonii (grass trees). This range of projects has resulted in nearly 200 publications in a variety of peer reviewed journals. 